\title{
The U.S. Coast Guard Academy American Service Academies Program Symposium: Advancing Leadership through Understanding the Holocaust
}

\author{
Alina M. Zapalska, Erik Wingrove-Haugland, and Abram Trosky \\ Department of Management, U.S. Coast Guard Academy New London, CT 06320 USA
}

\begin{abstract}
Holocaust and genocide education are important components of leadership education, for civilians and service members alike. The paper describes the US Coast Guard Academy's Holocaust symposium as an example of leadership education for service members that is equally applicable to other contexts of secondary and tertiary education (particularly in nations relying on volunteer militaries). The important lessons the symposium conveys include: 1) genocide is a threat to all humanity, and the loss of one group is a loss to all; 2 ) a bystander makes an active choice that may result in escalating harm to others; 3 ) prejudice has had a long history but it is still alive today; and 4) blind obedience to authority and leaders is dangerous. These experiences should lead students to not only recognize the social, political, and military antecedents to atrocity-producing situations, but help develop in them the moral judgment and courage to identify and prevent these conditions at home and abroad.
\end{abstract}

Open Access

Citation: Zapalska, A.M., Wingrove-Haugland, W., Trosky, A. (2017). The U.S. Coast Guard Academy American Service Academies Program Symposium: Advancing Leadership through Understanding the Holocaust. Interdisciplinary

Education and Psychology, 1(1):1.

Received: May 23, 2017

Accepted: June, 28, 2017

Published: July 8, 2017

Copyright: ๑ 2017 Zapalska et al. This is an open access article distributed under the terms of the Creative Commons Attribution License, which permits unrestricted use, distribution, and reproduction in any medium, provided the original author and source are credited.

\section{Corresponding author:}

Alina M. Zapalska,

Department of Management,

U.S. Coast Guard Academy

New London, CT 06320 USA.

E-mail: Alina.M.Zapalska@uscga.edu

\section{Keywords}

Holocaust education, ethics, leadership development, genocide and threat

\section{Introduction}

"The Holocaust provides us with awareness that democratic institutions and values are not automatically sustained, and that the Holocaust occurred because individuals, organizations and governments made a choice which legalized discrimination and permitted hatred and murderto occur."(Milton, 2000)

A series of coordinated, deadly attacks at seven locations around Paris killed at least 125 people and injured another 200 on Friday November $13^{\text {th }}, 2015$, just a week before the start of the American Service Academies Program (ASAP) Symposium at the U.S. Coast Guard Academy (USCGA). The coincidence of the deadliest terrorist attacks since 9/11could have distracted from with such a symposium; in this case, they served to highlight the importance of the topic of the ASAP Symposium: Lessons from the Holocaust.

While individuals in nearly all human societies have engaged in the systematic killing of other humans in civil, ideological, and international wars, there was a post-Cold War hope that the turn of the twenty-first century represented a departure from its predecessor - the bloodiest on record (Pinker, 2011). Keeping this hope alive requires that humanity must remember and apply the lessons of twentieth century conflict - particularly, how prejudice and disinformation can lead citizens of developed societies with broadly democratic institutions to justify and even participate in mass atrocity. The chief object lesson in understanding this danger is undoubtedly the Holocaust. Understanding how the Holocaust could happen is crucial to developing effective responses to today's atrocities, and to preventing widespread genocide in the future. 
For this reason, the USCGA Honors Program selected Lessons from the Holocaust as the theme of the 2015 ASAP Symposium. Although the Symposium focused on lessons from the Holocaust, its emphasis was on how those lessons can help us figure out how to respond to the Paris attacks and the Syrian refugee crisis, how to stop the ongoing genocidal campaigns in Iraq, Equatorial Africa, and Myanmar, and to reverse these and other conditions that have proven conducive to the growth of terror recruitment. This theme is all the timelier after subsequent events of 2016 and 2017, including the recent spate of attacks in Kabul, Baghdad, and the United Kingdom. The result of the 2015 ASAP Symposium was a unique educational event in which history and current events combined to illuminate each other and to enrich the experiences of participants in the program.

\section{LITERATURE REVIEW}

The Holocaust is one of the most horrifying, disturbing, and powerful illustrations of genocide in human history. Historians, political scientists, sociologists, psychologists, and theologians from all over the world have engaged in its grim accounting and wrestled with its implications. The Holocaust has become the standard through which other mass atrocities and convulsions of violence are perceived, presented, and sought to be prevented. Far more than a stain on the history of the German nation, where its denial or celebration is a crime, the Holocaust has become mankind's signature moral catastrophe.

During the first decades after the end of the Second World War, most Germans considered Hitler and the Nazi leaders to be solely responsible for the Holocaust, but they ignored the involvement of the German state and society in planning, organizing and implementing the genocide (Milton, 2000). Therefore, Holocaust education has focused on understanding the processes that brought about a mass murder and genocide. Perpetrators of the Holocaust were not only Nazi leaders like Hitler but also the SS and policemen who committed mass murder in the camps and at the shooting ditches or Polish streets during so called "Lapanka."

Beyond political and bureaucratic culpability, however, there are the more or less conscious decisions, actions - and, crucially, inactions - by citizens in German, Axis, Occupied, and Allied territories. Recognition of this diffusion of responsibility is central to combating the tempting misinterpretation which sees systemic violence as a purely top-down phenomenon by some inscrutable "other." This misattribution is, in part, what Arendt had in mind with her phrase, "the banality of evil" (Arendt,2005): the most disturbing aspect of terror is how otherwise decent individuals can become thoroughly desensitized to it.

While the Nuremberg Trials and other national, military, and international legal processes were able to convict and hold accountable those responsible for war crimes and crimes against humanity in the post-war period, the kind of collective guilt alluded to above could not be prosecuted on the basis of the existing criminal code after the collapse of the Nazi regime. A specifically moral analysis of history, conflict, and society recognizes the elusiveness of collective responsibility and helps overcome this problem in at least two complementary ways. First, it helps fill gaps in accountability by orienting contemporary law and policy toward victims, for example in the remuneration of families whose art and other property was stolen during the war.

Second, and more importantly, moral analysis of collective responsibility for atrocity helps reconstruct a more accurate and nuanced understanding of history as being for the living, with the specific aim of preventing the recurrence of its worst episodes. This particular use of history contradicts the sterile, objective, and amoral caricature of history as deterministic and therefore value-free; it is certainly no more so than politics. The primary lesson remains, however, that none of us ought to rely on others to do the crucial work of remembering for us, lest we collectively misremember, if not wilfully distort. This insight cuts to the very heart of the common but never clichéd phrase, "never again."

The central aim of Holocaust education is therefore to communicate this crucial concept of collective responsibility and to show how it highlights both individual autonomy (for example, the ability and responsibility to make moral judgments) and humans' fundamental interdependence. Each of us has both an individual and a collective responsibility to help prevent tragedies of this scale. The Shoah, though principally directed at Jews and their sympathizers, also befell Gypsies, socialists, homosexuals, and the disabled. It represents how any part of human identity, whether inscriptive like ethnicity or chosen like religion or party, can become the "other" - 
the object of another's hate. It also highlights our mutual vulnerability as humans as one ground for our mutual respect (Fineman, 2008).

Even if it is widely acknowledged that teaching about the Holocaust is a moral duty, it remains perhaps the most challenging task of 21 st century education. While most students are interested in learning about the history of the Second World War and even the Holocaust, they often react with discomfort and distress to the images and implications of that history. Ought we omit the worst of these images and descriptions for fear of what they might trigger in young adult learners, whether desensitization or hypersensitivity?

Scholars have labelled the Holocaustas one of the defining events of the twentieth century, and political and military leaders have confirmed never to allow mass murder or other systematic violence based on race, ethnicity, or religion to occur again (Gross, 2007; MacDonald, 2008). However, genocide has continued, very often in the context of warfare or state failure.It is therefore imperative for both future military leaders and citizens of free societies to possess a deep understanding of the contexts in which genocide or terrorism in any form arises and spreads, as well as the role soldiers and citizens have played in promoting and preventing them.

When servicemen and women of any rank lack knowledge of the role the military has historically played in perpetrating, perpetuating, or preventing past tragedies, they can be manipulated by unscrupulous leaders, civilian and military. The racial ideology that motivated the German government prior to and during WWII, for example, allowed and even encouraged actions unprecedented in human history. Therefore, it is critical to provide cadets with academic studies and leadership training opportunities that focus on the Holocaust and genocide issues.

Holocaust education requires educators to expose students to the moral and ethical elements of genocide and let them face the reality of crimes perpetrated, to commemorate the victims and to sustain a meaningful dialogue between history and memory. Many people risked everything to leave a trace of what happened to themselves, their families and their communities, so that their story would not be forgotten. Several scholars believe that academic programs have an obligation to the victims and their legacy, as well as to the survivors who speak for them, to ensure that their stories are heard and will be studied for generations to come (Burg, 2008; Rosenbaum, 2008).

Holocaust education, as part of human rights education which aims to develop an understanding of our common responsibility to make the enjoyment of human rights a reality in every community. This kind of education has been critical to political progress and transnational cooperation of the past decades,as well as the aggregate global decline in violence (Pinker, 2011). Human rights education not only concerns appreciating and respecting human rights, but also stimulating personal action in order to guarantee they are respected (Tibbitts, 2005). Human rights education, therefore, has a much broader scope than combating xenophobia, intolerance and racism. Particularly in developing countries, the most important objective is to help people realize self-empowerment by claiming the goods of peace and longevity. In this respect, promoting economic and social improvement is also an important objective for human rights education, including developing democratic and non-authoritarian educational systems.

Holocaust education and human rights education are thus both most effective when they are delivered together. In the absence of human rights education, Holocaust education becomes merely information about a sequence of historical events that sheds little insight upon contemporary atrocities and never addresses humanity's collective responsibility to prevent them. Without Holocaust education, human rights education remains completely abstract; we cannot fully understand the importance of human rights until we look at the disastrous consequences that result from asserting that certain groups are less than fully human, and thus do not have any human rights. When Holocaust education and human rights education are combined, however, they can lead students to understand how important it is to attribute human rights to everyone, and to work to end widespread violations of those rights.

\section{BACKGROUND ON THE USCGA}

While the USCGA may seem like an odd place to combine Holocaust education and human rights education, its mission, its students, and its focus on educating leaders of character make it perfectly suited for such an undertaking. The USCGA, located in New London, Connecticut, is the smallest of the United States federal military academies. It offers bachelor degrees in several majors: Civil, Electrical, Mechanical, and Marine Engineering, Naval Architecture, Government, 
Management, Operations Research and Computer Analysis, and Marine and Environmental Science. The USCGA's mission is to educate, train and develop leaders of character who are ethically, intellectually, and professionally prepared to serve their country and humanity.

Since 1876, leadership, honor, moral education, and ethics have permeated the training of the Corps of Cadets, including the enforcement of the Honor Code and Leadership training programs. An Academy-wide culture of leadership is required to facilitate learning across military, academic, and athletic programs. Cadets are exposed to the concepts of leadership, to moral-ethical philosophies, and to our core values of honor, respect, and devotion to duty through various curricular and extra-curricular programs. During four years of academic, military and athletic programs, the Commandant of Cadets, the Academic faculty, Department of Athletics, and the Leadership Development Center work together with the Corps of Cadets to guide and monitor cadets' development, their adherence to our core values, and their implementation of moral-ethical and leadership skills.

Figure 1. The U.S. CG's Leadership Model

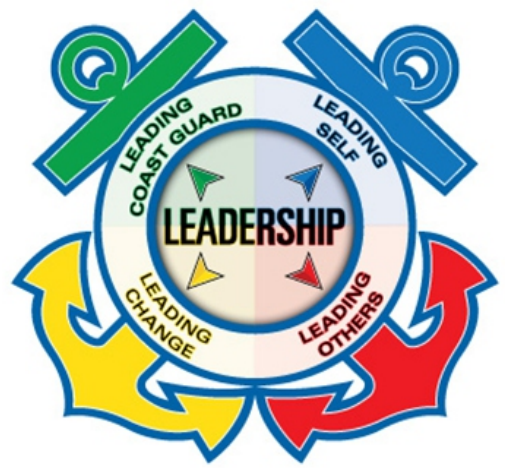

Source: U.S. Coast Guard

As illustrated in Table 1, USCGA cadets develop as leaders through four stages: leading self, leading others, leading performance and change, and leading the Coast Guard. This model,based on the CG leadership model (Figure 1),isadaptableto other academic institutions as they strive towards preparing future leaders for professions within both the private and the public sector. According to Table 1, these four stages require cadets to develop several competencies over four years: team building, communications, ethics, accountability, conflict management, and technical proficiency. During their freshman year, the focus is predominately on the competencies detailed in the "leading self" category. Freshman year is one of the most important stages of a cadet's academic life where much of self-discovery, understanding of the academic system, as well technical proficiency in the areas of study and learning begins. With each progressive year, the cadets shift their focus to the next set of competencies, while still working on mastering their skills in the previous categories.

\begin{tabular}{|l|l|l|l|}
\hline Leading Self & Leading Others & $\begin{array}{l}\text { Leading Performance } \\
\text { and Changes }\end{array}$ & $\begin{array}{l}\text { Leading the Coast } \\
\text { Guard }\end{array}$ \\
\hline $\begin{array}{l}\text { Accountability and } \\
\text { Responsibility }\end{array}$ & Effective Communication & Conflict Management & Financial Management \\
\hline Aligning Values & Team Building & Customer Focus & Technology Management \\
\hline Followership & Influencing Others & $\begin{array}{l}\text { Decision making and } \\
\text { Problem Solving }\end{array}$ & $\begin{array}{l}\text { Human Resources } \\
\text { Management }\end{array}$ \\
\hline Health and Well Being & Mentoring & $\begin{array}{l}\text { Management and } \\
\text { Process Improvement }\end{array}$ & External Awareness \\
\hline $\begin{array}{l}\text { Self Awareness } \\
\text { and Leaming }\end{array}$ & $\begin{array}{l}\text { Respect for Others and } \\
\text { Diversity Management }\end{array}$ & $\begin{array}{l}\text { Vision Development } \\
\text { and Implementation }\end{array}$ & Political Savvy \\
\hline Personal Conduct & $\begin{array}{l}\text { Taking care of } \\
\text { People }\end{array}$ & Creativity and Innovation & Partnering \\
\hline Technical Proficiency & & & $\begin{array}{l}\text { Entrepreneuship } \\
\text { Stewardship, Strategic } \\
\text { Thinking }\end{array}$ \\
\hline
\end{tabular}

Table 1. The USCGA's Leadership Development Framework 
Source: Commandant Instruction COMDTINST M5351.3, "Leadership Development Framework," United States Coast Guard, 2006.

The USCGA has developed an approach to developing leaders of character that consists of five basic components: academics, military, athletics, service learning, and learning through participation in clubs and student organizations, as presented in Figure 2.As Figure 2 illustrates, credit-bearing academic courses are only one of many methods for accomplishing the learning goals for the USCGA's cadets; this is especially true for goals related to leadership development. Some of the shared educational goals for cadets are achieved primarily through specially coordinated military, residential life, and co-curricular activities. Such learning is not classroombased and is not fostered by an instructive pedagogy. The extra-curricular learning goals typically focus on self-leadership skills, attitudes, and values; they help students apply knowledge and concepts in practical situations and provide opportunities for the integration and application of knowledge. Cadet learning outside the classroom occurs through contact with other cadets, through their interaction with particular programs, and through various environments in which they live, train, and work. Cadets have various opportunities to select, organize, and reflect upon their leadership learning experiences as part of their leadership development process.

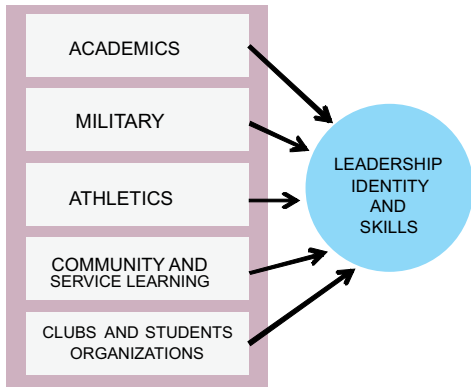

Figure 2. Leadership Development Framework at the U.S. Coast Guard Academy

Source: U.S. Coast Guard Academy

In addition to academics, students are challenged non-academically (militarily, athletically and socially) through daily interactions with each other, USCGA faculty and staff, and through structured military and athletic training opportunities. With over 30 NCAA sanctioned teams and multiple nationally ranked sports clubs, cadets have numerous opportunities to develop and practice their leadership skills. Through these three basic components, students learn to balance competing time demands for themselves and others. In order to meet the requirements of graduating cadets in four years, there is significant mentoring and advising that takes place throughout four years at the Academy. Three advisors (academic, military and athletic) work with each cadet to monitor cadets' moral/ethical, intellectual, personal, and professional development.

The academic component of leadership development is supported by a strong "Core Curriculum" which includes humanities, ethics, and leadership courses in addition to courses in science, math, engineering, and nautical science. This "Core" of 102 credits must be successfully completed by every cadet prior to graduation in addition to the requirements for a specific major. Two courses in particular, Moral and Ethical Philosophy and Organizational Behavior and Leadership, focus on the development of leaders of character. The Moral and Ethical Philosophy course covers traditional moral theories (such as utilitarianism, deontology, and virtue ethics) but also helps cadets develop their own moral voices and grapple with scenarios similar to those they are likely to encounter as Coast Guard officers. The Organizational Behavior and Leadership course covers theories of leadership (such as participatory, situational, and transformational leadership) and helps cadets develop their own personal leadership philosophy.

At the USCGA, academic and non-academic approaches to developing leaders of character are closely integrated with each other. For example, the Moral and Ethical Philosophy course focuses on the Coast Guard's core values of Honor, Respect, and Devotion to Duty, and works closely with the Cadet Honor Board to educate cadets about the importance of not lying, cheating, or stealing and to make recommendations regarding cadets who do so. The Organizational Behavior and Leadership course covers materials on leadership and "followership" which reinforce the efforts by our Cadets Against Sexual Assault organization to stress that there are no innocent bystanders: those who stand by and allow immoral acts to occur 
are guilty bystanders. This integration of academic scholarship and real-world application also informs our approach to teaching about the Holocaust.

\section{TEACHING THE HOLOCAUST AT THE USCGA}

Teaching and learning about the Holocaust calls attention to universal issues that are central to efforts to promote peace and mutual understanding. The USCGA Honors Program, under the leadership and supervision of the Director of the CGA Honors Program, provides its members with the opportunity to participate in the ASAP. This program is a three-week summer educational initiative that was created by the Auschwitz Jewish Center for select groups of cadets and midshipmen from the four U.S. military academies. The ASAP accepts cadets from all fields who exhibit a dedication to extracurricular endeavors, an interest in cultural issues and a strong commitment to community service. Most importantly, those selected cadets must demonstrate outstanding academic achievement, exceptional leadership potential, and strong communication skills in order to convey what they learned in Poland to their peers at the Academy. Over the last ten years, with funding provided by a class of 1955, the Honors Program was able to send sixteen cadets to the Holocaust summer training through the ASAP.

The ASAP Program provides an opportunity for cadets to visit the memorial sites, particularly at historic location of Oświęcim, Poland, which is vitally important to a deepened understanding of the Holocaust. Each year at the end of the ASAP, selected cadets from all Service academies travel to the Auschwitz Jewish Center. Visits to memorial sites are opportunities for holistic learning and chances to gain experiences that cannot be replicated in the classroom. They are also the culmination of Holocaust education in the ASAP, bringing together all the expectations and hopes relating to Holocaust education. During their trip to Poland, cadets visit the town that the Nazis renamed 'Auschwitz' after the annexation of Upper Silesia by the Third Reich at the beginning of WWII. They visit the spot where Heinrich Himmler ordered the construction of the camp in April 1940 (Auschwitz I), which in the following years expanded to include Auschwitz II Birkenau, Auschwitz III - Monowitz and more than 40 sub-camps.

In these solemn surrounds, cadets learn that during the first two years, Auschwitz was mainly a concentration camp for Polish prisoners (140,000 deportees), Soviet Prisoners of War (15,000 deportees) and other non-Jewish prisoners. From 1942, Auschwitz became the destination for mass deportations of Jews from all over Nazi-occupied Europe; 200,000 Jews were deported to Auschwitz-Birkenau in 1942, in 1943 around 270,000, and in 1944 more than 600,000. Students also hear that the majority of prisoners were never registered in the camp files as they were selected as 'unfit for work' by the SS and murdered in gas chambers upon arrival. By traveling to Auschwitz to study the Holocaust, CGA cadets learn that it was not an accident in history but a systematic atrocity facilitated by individuals', organizations', and governments' choices legalizing discrimination and encouraging prejudice, hatred, and, ultimately, mass murder.

The educational resources at the Auschwitz-Birkenau State Museum provide the future officers with a specially guided tour coordinated by the visitor service. The starting point for learning about history is the authentic site and the structural remnants of the camp. The guided visit for the cadets is delivered together with classes and group workshops, and discussions before viewing the different elements of the memorial site. Cadets can choose the thematic focus of visits and workshops, from 'Holocaust denial', 'from number to name',or 'finding the footprints'. A range of different preparatory materials is available for memorial site visits, and varies depending on specifically what cadets are expected to learn and study. The educational materials include contemporary witness reports, original documents and objects collected, which serve as proof that the past can be related to the present.

According to the CGA cadets' reports, the focus of the ASAP internship is to study the victims of Nazi crimes; those responsible for these crimes are also the subject of discussion, especially within the scope of the seminar events. Great importance has also been attached to the scholarly foundation of the educational work, based on the democratic values of inclusion and equality and a rejection of racism and anti-Semitism. Cadets mentioned that both the overall design of the site and its educational approach emphasize a thorough and independent examination of history on the part of visitors. The learning process through the site visit reflects not just the historical level, but also constructions of history. Various media and materials were available and taken into account.

Educating about the Holocaust through the ASAP helps future CG leaders and other armed 
forces understand key concepts that are critical when studying other examples of mass violence or terrorism. When cadets explore the history of atrocity, contemporary acts of terror, or massive human rights violations, they are able to draw on their understanding of the Holocaust and become more aware of their own responsibilities as both global citizens and leaders in armed forces. Given the contemporary realities of twenty-first century terror, state violence, and oppression, a careful study of the Holocaust provides a comprehensive understanding of the political, economic, and social ramifications of the many faces of discrimination, prejudice, and intolerance.

The identification of groups as "others", their stereotyping, stigmatization, de-humanization and ultimate destruction familiar from the treatment of Jews, Roma, homosexuals, and others by the Nazis, is replicated in the genocide of the Tutsi in Rwanda (1994), the ideologically-driven class warfare of the genocide in Cambodia (1975-1979), and most recently in the so-called Islamic State's campaign of systematic rape and killing of ethnic and religious minorities in Syria and Iraq. An analysis of the socio-cognitive, cultural, and political mechanisms that led to the Holocaust helps the ASAP participants from all service academies recognize the importance of accepting and appreciating diversity rather than seeing it as a threat, particularly during times of scarcity and/or rapid change. Teaching and learning about the Holocaust sensitizes cadets to the difficult circumstances minorities and refugees face, as well as the danger that nationalist and fundamentalist ideologies pose in justifying cruelty toward out-groups.

\section{2015 USCGAASAP SYMPOSIUM - AUSCHWITZ' LIBERATION 70 YEARS ON}

Not withstanding an overall downward trend in crime and violence (Pinker, 2011), recent years have witnessed a trebling of hate groups in the United States, including a threefold increase in anti-Muslim groups, reported by the Southern Poverty Law Center (2017), and a troubling popularization of far-right parties and ideologies in Europe. 2015 also marked the emergence of the so-called Islamic State, whose quest for the establishment of an Islamist Caliphate has metastasized into ISIS-inspired terror attacks around the world, most recently in the Philippines, France, and United Kingdom.

In the absence of a formal institutional platform exposing each cadet to the danger of virulent terrorist ideologies such as those leading to the Holocaust and injustices of Nazi regime, USCGA is committed to broadening cadet exposure to the Holocaust beyond the relatively few cadets who are able to visit the concentration camp sites. To this end, USCGA held the 2015 USCGA ASAP Holocaust Symposium on Saturday, 21 November 2015. At this symposium, the CGA Honors Program hosted cadets and midshipmen from the US Military Academy (USMA) and US Air Force Academy (USAFA), as well as several Alumni of the ASAP Program and students from Connecticut College, for the 2015 USCGAASAP Holocaust Symposium.

The 2015 USCGA ASAP Symposium was organized to expand cadets' knowledge of the Holocaust, and to speak out about national socialist and other ideologies in the context of cultural, educational, and state institutions. The goal of the symposium was to promote awareness about genocide and the ethical dilemmas armed forces officers face during commissioned service. Several cadets who were selected for the ASAP Holocaust Internship from their respective academies (USCGA, USAFA, USNA, and USMA) by the Museum of Jewish Heritage in New York City to study genocide and the Holocaust in Oswiecim, Poland between 2008 and 2015 volunteered to participate in the Symposium and share their experience visiting the concentration camp sites.

The ASAP Symposium was organized through the USCGA Honors Program to provide cadets with an authentic learning experience about the Holocaust and issues related to genocide, terrorism, injustice, intolerance, and atrocity that extend beyond what they are taught in the classroom. This was the second ASAP Symposium organized by the Honors Program since 2008, this time on the 70th anniversary of the liberation of Auschwitz. As the ASAP supports the mission and makes the USCGA the center of academic excellence on leadership education and Holocaust training, the Honors Program brought together cadets from participating academies to discuss moral and ethical issues of Holocaust, genocide, and terrorism with USCGA staff, faculty, and cadets. Members from the Museum of Jewish Heritage in New York City were also in attendance, including the director of the ASAP Fellowship, Ms. Shiri Sandler.

After a short presentation by Ms. Sandler on the history and objective of the ASAP program, USCGA Cadets and Midshipmen andAlumni of the ASAP from the ten eight years participated in 
a discussion panel to share their experiences from attending the ASAP and studying in Poland. This discussion included all 4/c (freshman) USCGA cadets, faculty and staff, with USCGA's Academic Dean and Commandant of Cadets in attendance, and was followed by a Q\&A.Most of the questions posed pertained to cadets' experience from the ASAP and how that experience and lessons from visiting the Auschwitz concentration camp enriched their understanding of theethics and outcomes ofleadership and followership actions. As illustrated in their comments below, the discussion and exchange of opinions led many $4 / \mathrm{c}$ cadets to appreciate the importance of recognizing diversity, respecting difference, and the dangers of failing to do so. The Symposium also opened up a platform for discussion on the importance of leadership and silent followership in organizations by focusing on individuals who were neither victims nor murderers, but whose silence made the Holocaust possible.

Some of the comments about the ASAP Symposium provided by our cadets included:

“...This Symposium helped foster an environment of understanding, helped cadets gather an appreciation for the democratic society which they were a part of, and informed them about the implications of genocide, violence, and intolerance. In the fleet, all officers need to understand the implications of ethnic tension, develop a global mind-set, and serve with respect. The Symposium also informed cadets about the dichotomy between the former USSR and the contemporary 21st Century American Republic in which they live."

"...cadets learned to recognize the danger of being a silent bystander when wrong or unethical actions are committed and as future officers they should develop and have the ability influence the world in a positive way...."

"...the Holocaust as the systematic annihilation of the Jews and othergroups by Nazi Germany must be taught in a manner that leads to an understanding of the ramification of prejudice, racism and stereotyping, and an examination of what it means to be a responsible and respectful person for the purpose of encouraging tolerance of diversity in a pluralistic society...."

"... I think the Symposium had a big impact on cadets who participated. In my opinion cadets learned that they and all people must demonstrate behaviors that are respectful of individuals regardless of differences based upon factors related to race, ethnicity, religious affiliation, gender, disability, economic status or sexual orientation. They will also demonstrate a willingness to take proper action when observing or becoming aware of a violation of human rights..."

"...The seminar provided a lesson on how cadets should take appropriate action when confronted with information intended to distort or deny history, such as that presented by deniers of the Holocaust and the Armenian Genocide. I think those cadets who participated would be able to continue to assess their understanding of human nature and apply their newly acquired understandings to the way they lead their lives as private citizens and the leaders of the US Coast Guard...."

The second part of the Holocaust Symposium consisted of a lecture Lessons from the Holocaust delivered by Professor Wingrove-Haugland, Professor of Morals and Ethics at the USCGA, where he discussed ethical and moral issues behind the Holocaust in the context of the leadership and followership. Professor Wingrove-Haugland provided a platform for group discussions on the lessons learned on moral and ethical issues of the Holocaust. The twelve lessons of the Holocaust are presented and discussed in section five of this paper.

After Professor Wingrove-Haugland delivered his lecture on the Lessons from the Holocaust, the USCGA cadets and the guests worked in discussion groups on the lessons from the Holocaust. Dr. Wingrove-Haugland provided group discussion topics that covered the following lessons from the Holocaust: 1) Progress does not prevent atrocities; it magnifies them; 2) Civilization is no immunization against evil; 3) Evil exist; 4) Good people also exist; 5) Most of us are somewhere in the middle; 6) Each of us is capable of doing more harm than good; 7) There are no innocent bystanders; 8) The worst thing you can do is to consider someone less than human; 9) The best thing you can do is to acknowledge someone's humanity; 10) Hitler and the Nazis were human beings, not sub-humans; 11) Those who remember the past often end up repeating it anyhow; and 12) Saying "never again" is not enough.

Through discussion and exchange of opinions, the participating cadets and midshipmen came to better appreciate the ethical implications of the Holocaust. Specifically, they attest to 
understanding that genocides occur because people and governments make decisions that perpetuate and deepen discrimination and routinize or even celebrate its persecution. Focusing on those social and political choices yielded valuable insights into the making of history and preventability of instances of genocide and crimes against humanity - germane to the particulars of intervention and non-intervention in Syria and Iraq. Elaborating the "never again" message, one central lesson from these twelve points presented by Professor Wingrove-Haugland is that man-made catastrophes are neither accidents of history, nor determined; supporting human rights norms in one's company, branch, and nation are part of a larger, ongoing, perennial struggle to make the promise of social and global justice real in the world. When studying the Holocaust, cadets realize the complexity of genocide and that those events cannot be simply explained but are the result of multiple historical, economic, religious and political factors. This in turncontributes to the understanding that preventing genocide and mass atrocities can begin with the identification of warning signals in one's own society.

During lunchtime, Mrs.Gisela Marianne Adamski, a Holocaust survivor, spoke about her Auschwitz experience during the 1940s. Mrs. Adamski stated that after surviving the horrors of Auschwitz, she developed a strong obligation to share her Holocaust experience. During her testimony, Mrs. Adamski stated that no one should ever have to live through what she and other prisoners of the Nazi's camps went through. Her testimony added greatly to cadets' understanding of history and enriched their experiences on Nazi's genocide. Mrs. Adamski concentrated on the various destructive policies carried out by Nazi Germany and its collaborators and she paid attention to the policies particular to a given genocide.

By listening to a personal story,those in attendance uniquely benefitted from an individual experience of life before and after the Holocaust, emphasizingthe cultural and historical dimensions of genocides and crimes against humanity. A careful comparison of the Holocaust with other examples of systematic discrimination and violence that took place in the Soviet bloc such as the Katyn massacre and bloody repression of dissent by communist governments in Poland and Hungary, helped cadets to identify common patterns. Discussion during lunch facilitated the understanding of similarities and differences between atrocity, mass violence, ethnic cleansing, and genocide.

The Symposium participants were able to study and work in groups to explain that the Holocaust has the characteristics that appear in other genocides (e.g., a specific victim group or groups, mass violence against that group, and deprivation of the essentials for human existence), but that it also contains elements that cannot be found prior to its occurrence. Cadets discussed the motivations behind the intention of the Nazis to murder each and every Jew in the territories under their domination. Furthermore, they focused on the genocide of the Jewish people that served no pragmatic purpose. Cadets learned through discussion that while other genocides and mass atrocities often have economic, political, or military motivations, the murder of the Jews had none of these incentives. The purpose was to have cadets understand that the Nazis' destruction was based on a racist ideology which held that "Race is the decisive and melding force in the life of nations. Language, culture, customs, piety, traditions, lifestyle, but also laws, governmental forms and economies, the whole variety of life is racially determined" (Der Reichsführer SS/SS Hauptamt, Rassenpolitik, Berlin, 1943). By examining this history, cadets increased their awareness of the danger of racist ideology in the contemporary world, foregrounding an appreciation for the universality of human and group rights.

During the ASAP Symposium, cadets were involved with presentations and discussions about the atrocities of the Holocaust in order to learn about the importance of this tragic episode in world history and the role of leadership in the development of respect and acceptance of diversity. The goal was to provide an opportunity for the cadets to learn that both respect and acceptance of diversity are fundamental principles for the functioning of democratic nations, strong militaries and effective transnational organizations. The USCGA understands that the history of the Holocaust provides a background to convey the centrality of the basic moral principles underpinning the international human rights regime, and that its study is a prime opportunity to convey the ongoing importance of the democratic values of pluralism and recognition. Symposium attendees are expected to learn how silence or indifference in the face of others' suffering can magnify injustice, ignorance, and inequality. Specifically, the symposium emphasizes citizens and service-members' responsibilities in light of the lapses of each in the run-up to the Holocaust and similar catastrophes, providing an outstanding educational experience for future military officers extending beyond what cadets are taught in their Academy 
classrooms.

Group discussions and study of the Holocaust during the USCGA ASAP Symposium led cadets to think about political responsibilities and explore the functioning of governmental structures. As the Holocaust was a State enterprise legitimized by the law, its study clearly raises questions of the use and abuse of political power for violent purposes on a national level and, ultimately, on an international level. For instance, an understanding of the role of governmental and quasi-governmental organizations and paramilitary units in attacking and almost destroying the Jewish population, not only of Germany but of most of Europe, will raise cadets' awareness about the roles and responsibilities of the State, of individuals and of society as a whole in the face of increasing human rights violations. These experiences should lead cadets to go beyond a simple commitment not to participate in atrocities themselves, and help them develop the moral courage they will need to prevent others from committing such atrocities.

\section{The Lessons of the Holocaust by Professor Erik Wingrove-Haugland}

Professor Erik Wingrove-Haugland in his speech during the ASAP symposium stated that as the Holocaust occurred recently some survivors are still alive and they can speak to us today and bring to us lessons that modernity will not, in and of itself, prevent atrocities. Professor Wingrove-Haugland stated that in the 19th century, there was a widespread optimism that, as science continued to make progress, human beings would become better and better. He stated that the Holocaust shows that this is not true; our technology may be improving, but human beings are not; as a result, our technology merely allows us to commit atrocities on a larger scale. This is the first lesson of the Holocaust: progress does not prevent atrocities, it magnifies them.

Professor Wingrove-Haugland mentioned that a second thing that always strikes him about the Holocaust is where it happened. This was no uncivilized backwater, like Pol Pot's Cambodia in the 1970s; this was Europe, this was Germany, this was the land of Bach and Beethoven, of Herder and Goethe, of Kant and Hegel. This was the height of civilization. This reveals the second lesson of the Holocaust: civilization is no immunization against evil.

Professor Wingrove-Haugland used the word "evil" deliberately as this is the third lesson of the Holocaust: that evil exists. In the early 20th century, some anthropologists and ethicists developed a view known as cultural relativism, which asserts that nothing is right or wrong, since morality is relative to the views of a culture and no culture's views are right or wrong. The Holocaust made relativism implausible; it showed us that there are some things that are just plain wrong, that evil does, in fact, exist.

We also learned that the Holocaust is not only the story of Hitler and Eichmann; it is also the story of many heroes who saved their potential victims, often at great personal cost. Some of these are well known, like Oskar Schindler and Raoul Wallenberg; others, like Andre Trocme who led the city of Le Chambon's efforts to save about 4,000 Jewish children, or the Hardagas, a Muslim family in Yugoslavia who sheltered Jewish refugees, are heroic stories waiting to be told to a wider audience. There are others whose names we will never know, because either they or the people they helped died before their story could be told. As Professor Wingrove-Haugland states the Holocaust was a horrible event, but we distort its memory if we fail to learn the fourth lesson from the Holocaust: that there are good people who are willing to stand up against evil, even at the risk of their own lives. The Holocaust not only shows us the depths to which humanity is capable of sinking, but also the majestic heights towards which we are capable of soaring, even under the most adverse conditions.

While the Holocaust shows us that some people are willing to risk their lives to help others, it also shows us that such people are rare. Those who helped the potential victims of the Holocaust constitute what Timothy Snyder calls the "righteous few." While a few good people were willing to stand up against the evil of the Holocaust that is precisely what most people did: nothing. While evil exists, and good people exist, the fifth lesson of the Holocaust is that most of us fall somewhere in between; the vast majority of humanity falls somewhere on the scale between the banal evil of Eichmann and the reflexive goodness of Andre Trocme.

The difference in scope between what Hitler and Eichmann accomplished and what Oskar Schindler and others accomplished shows us the fifth lesson of the Holocaust. There is debate today regarding how much positive impact one human being can have on the world as a whole, but there is no debate regarding the fact that one human being, or a few human beings, can have a massive negative impact on the world. We learned this from the Holocaust, but we see it 
confirmed every day in terrorist attacks and suicide bombings, and in the mass shootings that have become commonplace in our society. The sixth lesson of the Holocaust is that the harm each of us is capable of doing is far greater than the good each of us is capable of doing.

The seventh lesson of the Holocaust is a lesson we are trying to teach cadets today regarding sexual harassment and assault: there are no innocent bystanders. Someone who witnesses an immoral act and does nothing to prevent it is a guilty bystander. We need to stop being bystanders and start being "upstanders" who stand up for others when they are being mistreated. Hopefully, most of us will never have to discover whether we would be willing to risk our lives to save Jews from the Holocaust, but we can at least risk some social disapproval to prevent people from being harassed or persecuted.

Why didn't more people help save the victims of the Holocaust? Fundamentally, for the same reason that the Nazis were massacring them: because they did not see those victims as human beings. This is the eighth lesson of the Holocaust: the most negative and dangerous thing any human being can do is to deny that someone is a human being. Only by viewing Jews, Romani, communists, Poles, homosexuals, people with disabilities, Freemasons, and Slovenes as untermenschen or "subhumans" were the Nazis able to murder millions of them. Only by getting the common people and the international community to view them in the same way were they able to prevent anyone from stopping them from doing so. Once someone's humanity has been removed, as the Holocaust shows, there are no limits to the ways in which they can be treated; even treatment that would be considered cruelty to animals no longer appears unjustified. The Holocaust and the numbers tattooed on people in the concentration camps are the ultimate example of treating human beings as objects, and using them merely as a means to an end.

Of course, this above mentioned lesson leads to a ninth lesson of the Holocaust: the most positive thing a human being can do is to acknowledge the humanity of another human being. This is what motivated those "righteous few" to save thousands of potential victims from the death camps: they saw those victims as human beings. It is also why, when these moral heroes were asked why they risked their lives to save people they didn't even know, many of them were unable to understand the question; most responded in the way the Andre Trocme's wife, Magda, did; she shrugged and said "what else could we do?"

The Nazis did not hate Jews because of their religious beliefs and practices; they hated the Jews because of what they called their "blood." While any kind of treating others as subhuman is immoral, atenth lesson of the Holocaust is that it is particularly immoral to treat others as less than fully human because of who they are, rather than what they have done. This is partly because we cannot change who we are; those whom the Nazis considered to have "Jewish blood" could not get rid of it while remaining alive. Since we did not create ourselves and we cannot change who we are, treating others as subhuman simply because of who they are adds the immorality of unjust discrimination to the already immoral act of treating others as subhuman. This is why racism and sexism are particularly objectionable: they treat others as less than fully human because of who they are.

An eleventh lesson of the Holocaust is that those who do remember the past often end up repeating it anyhow. The Nazis were not ignorant regarding history; they were avid readers of history, which they interpreted as the story of struggle between various races. Remembering the past is a necessary condition for not being condemned to repeat it, but it is not a sufficient condition. To avoid being condemned to repeat the past, we also need to learn its lessons, and to commit ourselves to not making the same mistakes in the future.

The same is true of the twelfth lesson from the Holocaust, which is actually in many ways the first lesson and most important lesson. The most common and most important lesson from the Holocaust is usually stated simply as "never again." We must acknowledge that, on a smaller scale, the Holocaust has already happened again, many times, in the past 70 years. Stalin's purges and gulags, which began before the Holocaust and continued after the war ended, are only one of many examples. Here is a partial list of genocides with 10,000 victims or more that have occurred since 1945, in roughly chronological order: Tibet, Zanzibar, Guatemala, the Sikhs in India, Bangladesh, Burundi, Equatorial Guinea, East Timor, Indonesia, Laos, Argentina, Ethiopia, the Kurds in Iraq, Brazil, the Congo, Rwanda, Somalia, Sri Lanka, Bosnia, Cambodia, Sudan, the Yazid is in Syria and Iraq. None of these comes close to the scope of the Holocaust, of course, or to the depth of its atrocities; indeed, we can get a sense of the incredible scope of the Holocaust by realizing that more people were killed during the Holocaust than in all of the other genocides that I just mentioned put together. The fact that genocides have been smaller during 
the past 70 years, however, does not make them any less morally objectionable, nor does it minimize our duty to prevent them. While it is very important to say "never again," these ongoing genocides reveal the twelfth and final lesson of the Holocaust: that saying "never again" is not enough.

At the end of presentation, Professor Erik Wingrove said that today, Europe is in the middle of the largest refugee crisis since millions fled Germany and German-controlled areas in the 1930s and 40s. While Europe is now economically integrated, it is facing an economic crisis which threatens to recreate the economic conditions of the late 1920s and early 1930s that provided fertile soil for Hitler and his followers.

The most recent attacks on Paris, London, Berlin, and Stockholm challenge our ability to recognize and respond to evil without branding billions of people as evil based on the behavior of a tiny number. There are plenty of opportunities for us to rise to the challenges of our day. If we learn the lessons of the Holocaust, and combine our fervent prayer with practical actions to prevent future atrocities and disasters from occurring, we can turn "never again" from a prayer into a promise, and then into a program for achieving that promise. While nothing will ever bring back those who were murdered in the Holocaust, this is the best way to honor their memories and to ensure that they did not die in vain.

\section{CONCLUSION}

The Holocaust is the pivotal event of the modern era, if not human political history. Such unprecedented evil still serves as a sobering reminder of human depravity and responsibility seventy years on. The study of the Holocaust requires an understanding of social and political processes such as persecution of minorities and racial intolerance, and an awareness of their relevance to current societal problems. Studying the Holocaust provides a context for exploring the dangers of remaining silent, apathetic, and indifferent in the face of the oppression of others.

Holocaust history demonstrates how a modern state such as Germany utilized its technological expertise and bureaucratic infrastructure to implement destructive policies ranging from social engineering to genocide. Studying the Holocaust helps cadets think about the use and abuse of power, and the roles and responsibilities of individuals, organizations, and nations when confronted with civil rights violations and policies of genocide. As students gain insight into the many historical, social, religious, political, and economic factors that cumulatively resulted in the Holocaust, they gain awareness of the subject's complexity and a perspective on how a convergence of factors can contribute to the disintegration of democratic values. Students come to understand that it is the responsibility of citizens in any society to learn to identify danger signals, and to know when to react.

The USCGA Honors Program recognizes that the history of the Holocaust provides one of the most effective, and most extensively documented, subjects for a pedagogical examination of basic moral issues. A structured inquiry into Holocaust history yields critical lessons for an investigation of human behavior. A study of the Holocaust also addresses one of the central tenets of education in the United States, which is what it means to be a responsible citizen, officer, and leader. Through a study of the Holocaust, cadets also come to realize that democratic institutions and values are not automatically sustained, but need to be appreciated, nurtured, and protected. They learn that silence and indifference to the suffering of others, or to the infringement of civil rights in any society, can unintentionally perpetuate the problem. The cadets who participated in this Holocaust Symposium learned that the Holocaust was not an accident in history; it occurred because individuals, organizations, and governments made choices that not only legalized discrimination but also allowed prejudice, hatred, and ultimately mass murder to occur. 


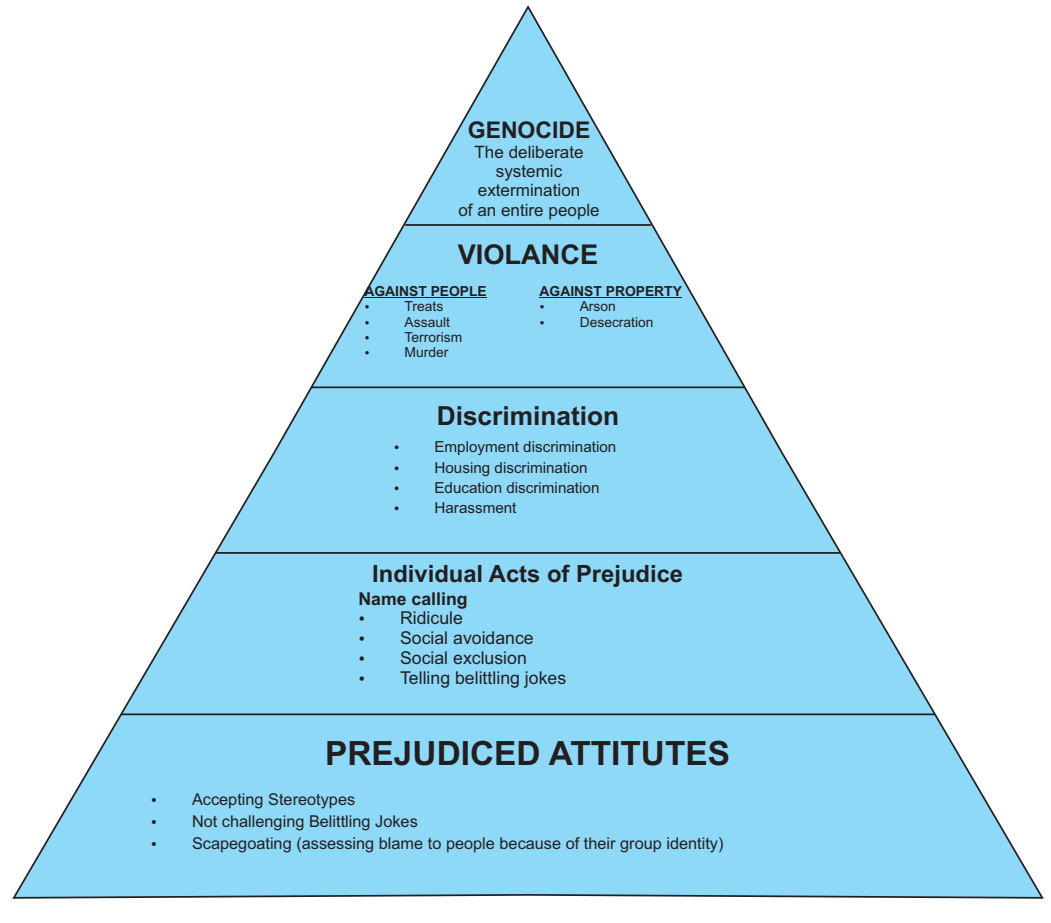

Pyramid of Hate, ( 2005 Anti-Defamation League

Figure 3. Pyramid of Hate

Source: 2003 Anti-Defamation League and Survivors of the Shoah Visual History foundation; Washington State Holocaust Education Resource Center

Teaching about the Holocaust raises challenges for educators as the material they teach leaves students struggling with disturbing ethical questions. Teaching and learning about the Holocaust, and the history of genocide, provides an opportunity to engage students in deep reflection on the origins and mechanisms of violence, so that they can better understand the past and the world they live in when terrorism and genocide become every day realities. Holocaust education is essential today and is necessary to raise awareness about a shared history, to promote human rights everywhere and eliminate all forms of discrimination, intolerance, genocide, and terrorism. It also teaches that prejudiced attitudes, acts of prejudice, discrimination practices, and violent acts are primary factors that can lead to genocide as illustrated in the Pyramid of Hate (Figure 1).

The CGA Honors Program also considers the Holocaust and genocide education to be critical for the Academy's leadership, as it contributes to the USCGA's broader effort to produce ethical leaders with empathy for and understanding of people of diverse cultural backgrounds. The ASAP represents a unique opportunity to develop more historically-minded leaders, strengthen the moral fibres of the USCG mission, and contribute to the development of practical and effective responses to the plague of genocide. Overall objectives for the 2015 USCGA ASAP Holocaust symposium included and supported the following lessons proposed by the Holocaust Education Resource Center, Washington State: human cruelty has been apparent in a variety of historical circumstances; seemingly benign racist jokes and slurs are stepping-stones to genocide; genocide is a threat to all humanity, and the loss of one group is a loss to all; a bystander by doing nothing makes an active choice that may result in escalating harm to others; prejudice has had a long history and is still present today; blind obedience to authority and leaders is dangerous; when tyranny prevails, individuals can make a difference by acting with moral courage; and blocking the progression from the bottom of the 'Pyramid of Hate' to the topwill help ensure that acts of genocide would never take place again.

Teaching about the Holocaust is to ask why a civilized western democracy in the 20thcentury brought a totalitarian regime.In studying the Holocaust,students begin to see the power of language, derogatory speeches, and nuanced political statements. Today, it is critical to educate students all levels of education about the consequences and the effects of the Hitler's regimethat led to humiliation, intimidation, and violence. Academic programs at secondary and tertiary educational institutions must take a full responsibility for preparing our students to meet the moral challenges of the twenty-first century. Holocaust education should be a continuous 
processspecifically designed to students' intellectual capacitystarting at the earliest appropriate level of education through college.Students must learn that violence and injustice begin with small steps of indifference and conformity and that bystander behavior, while seemingly small, on aggregate can affectour history. To that same end, Holocaust education elevates the actions of otherwise forgotten heroes - individual citizens and soldiers whose dissent and/or protection of persecuted minorities risked they and their families' freedom, person, and property, illustrating the highest in human courage, empathy, and resilience.

In sum, Holocaust education provides the most effective way into an examination of the complexities of moral judgment in the context of social conformity and political and religious obedience. Holocaust education must convey that genocide was not an accident in history but occurred because individuals, organizations, and governments made choices legalizing discrimination, and allowing prejudice and hatred to spread. Similarly, silence and indifference to the suffering of others, including the violation of civil rights, has moral/spiritual, social/political, and historical/economic consequences that can contribute to the rapid disintegration of democratic values. For "never again" to be more than cliché, teachers and students of history have a responsibility to highlight the agency of individual citizens and especially leaders in identifying danger signals and knowing when and how to address them. 


\section{References}

Arendt, H. (2005). Responsibility and Judgment. New York: Schocken.

Burg, A. (2008). The Holocaust is Over: We Must Rise from Its Ashes. London: Palgrave Macmillan.

Fineman, M. A. (2008). The Vulnerable Subject: Anchoring Equality in the Human Condition. Yale Journal of Law and Feminism. 20(1): 8-40.

Gross, J. (2007). Fear: Anti-Semitism in Poland afterAuschwitz. New York: Random House.

MacDonald, D. B. (2008).Identity Politics in the Age of Genocide: The Holocaust and Historical Representation. London: Routledge.

Milton, S. (2000). Holocaust Education in the United States and Germany, in: Learning from History, The Nazi Era and the Holocaust in German Education. (eds.) Annette B.et al, Bonn.

Pinker, S. (2011).The Better Angels of Our Nature: Why Violence Has Declined. (1st ed.)London: Penguin.

Rosenbaum, A. S. (2009). Is the Holocaust Unique? Perspectives on Comparative Genocide. (3rd ed). Boulder, CO: Westview Press.

Southern Poverty Law Center.(2017). Hate groups increase for second consecutive year as Trump electrifies radical right. retrieved from https://www.sp/center.org/news/2017/02/15/hate-groupsincrease-second-consecutive-year-trump-electrifies-radical-right

Snyder, T. (2015).Black Earth: The Holocaust as History and Warning. New York: Random House.

Tibbitts, F. (2005). Transformative Learning and Human Rights Education: Taking a Closer Look. Intercultural Education, 16(2): 107-113.doi: 10.1080/14675980500133465 